Agnieszka Siwek, Józef Cezary Kałużny, Działalność naukowa ks. Władysława Żyły na uniwersytecie we Lwowie. Zarys zagadnienia, [w:] Starożytność chrześcijańska. Materiały zebrane, red. Józef Cezary Kałużny, t. 4, Kraków 2016, s. 151-161.

DoI: http://dx.doi.org/10.15633/9788374385282.09

\author{
Agnieszka Siwek, Józef Cezary Kałużny
}

UNIWERSYTET PAPIESKI JANA PAWŁA II W KRAKOWIE

\title{
Działalność naukowa ks. Władysława Żyły na uniwersytecie we Lwowie. Zarys zagadnienia
}

Władysław Żyła urodził się 21 stycznia 1877 roku w Bursztynie, niewielkim mieście we wschodniej Małopolsce. Był synem Walentego, pracownika kolei. Po ukończeniu w roku 1895 gimnazjum w Stanisławowie, wstąpił do Seminarium Duchownego we Lwowie. Równocześnie kształcił się na Wydziale Teologicznym tamtejszego uniwersytetu. Został wyświęcony na kapłana w 1899 roku. Zdolnego kleryka zauważył abp Józef Bilczewski, który wysłał go po święceniach na studia teologiczne do Rzymu i Innsbrucku (lata 19001902); młody kapłan zwieńczył je uzyskaniem w 1902 roku tytułu doktora teologii. Wydaje się, że już w trakcie pobytu w Rzymie zainteresowania ks. Żyły kierowały się w stronę sztuki kościelnej, jednak po powrocie do Galicji przydzielono mu funkcję katechety w szkołach we Lwowie i w Tarnopolu ${ }^{1}$.

W trakcie działalności dydaktyczno-duszpasterskiej we Lwowie w kapłanie musiały dojrzewać zainteresowania naukowe, ukierunkowane właśnie na sztukę, skoro po niemal dziesięciu latach (1911) odbył podróż do Salzburga i wziął udział w zjeździe historyków sztuki kościelnej. W liście do swojego biskupa, relacjonując swój pobyt, pisał, że dzięki udziałowi w tym spotkaniu nauczył się bardzo wiele w zakresie konserwacji. Uważał, że sztuka kościelna

1 J. Wołczański, Wydział Teologiczny Uniwersytetu Jana Kazimierza we Lwowie 1918-1939, Kraków 2002, s. 378; K. Gabryel, Żyła Władysław, [w:] Słownik polskich teologów katolickich, red. H. Wyczawski, Warszawa 1983, s. 559-561; E. Bulanda, Śp. Ks. Władysław Żyła, „Kwartalnik Historyczny" 39 (1925), s. 417-419. 
służy większej chwale Bożej: „ma przybliżać duszę do Boga i [...] ma budzić uczucia religijne, dlatego" tak ważna jest renowacja zabytków². Za zgodą i przy pomocy abp. Józefa Bilczewskiego lato 1912 roku spędził we Włoszech, w podmediolańskim Bergamo. Zbierał tam materiały do opracowania monografii renesansowej kaplicy Colleoniego ${ }^{3}$. Po miesięcznym pobycie w Italii ks. Żyła udał się do Paryża, gdzie w czasie semestru zimowego roku akademickiego 1912/1913 studiował historię sztuki w kilku instytutach: na Sorbonie, w Akademii Sztuk Pięknych, École du Louvre i Collège de France. W przeciągu trzech miesięcy (od listopada 1912 do stycznia 1913) udało mu się zaliczyć imponującą liczbę 197 wykładów. Fakt ten informuje nas z jednej strony o tym, jak szerokie zainteresowania posiadał kapłan, a jednocześnie, jak gorączkowo próbował on nadrobić „stracony” czas ${ }^{4}$. Podczas tego wyjazdu zbierał materiały do swoich późniejszych publikacji, m.in. na temat kaplicy św. Ludwika5.

Arcybiskup Józef Bilczewski, który nie tak dawno sam pracował na Uniwersytecie Lwowskim, zdawał sobie sprawę z tego, że od śmierci ks. Eustachego Skrochowskiego (1843-1895) wakowała Katedra Estetyki Kościelnej. Sam zresztą zainteresowany rozwojem na Uniwersytecie tych dyscyplin (sztuki kościelnej i archeologii chrześcijańskiej), które wykorzystywał w swoich studiach nad początkami Kościoła, mile widział starania ks. Żyły, kierujące jego badania właśnie w stronę sztuki i archeologii ${ }^{6}$. Widoczne jest wsparcie arcybiskupa, który w swoim dzienniczku pod datą 10 marca 1913 roku odnotował: „byłem w minist[erstwie] oświaty; ministra nie było; u Ćwikl[ińskiego] [...] poleciłem sprawę habilit[acji] X. Lisowskiego,

2 Archiwum im. Arcybiskupa Eugeniusza Baziaka [dalej: A Bк], b. sygn., teczka personalna ks. Władysława Żyły: List ks. Władysława Żyły do abp. Józefa Bilczewskiego, Tarnopol 11.09.1911.

3 A BK, b. sygn., teczka personalna ks. Władysława Żyły: List ks. Władysława Żyły do abp. Józefa Bilczewskiego, Bergamo 15.09.1912.

${ }_{4}$ A B K, b. sygn., teczka personalna ks. Władysława Żyły: List ks. Władysława Żyły do abp. Józefa Bilczewskiego, Paryż 27.01.1913. Tematyka wykładów: architektura gotycka Francji XIv i Xv wieku; sztuka hiszpańska za Karola v, Filipa II, Filipa III i Iv; sztuka grecka epoki hellenistycznej; malarstwo weneckie w xv wieku; historia architektury; rzeźba włoska XV i Xvi wieku etc.

5 Również ta praca została ukończona i opublikowana. Zob. Derżavnyj Archiv L’vivskoji Obłasti u L’vovi [dalej: DALo], Pismo dziekana wT UJK ks. Franciszka Lisowskiego do ministra WRiop, Lwów 26.04.1919, f. 26, op. 5, nr 669.

${ }^{6}$ Szerzej patrz: J. C. Kałużny, Święty Józef Bilczewski badacz starożytności chrześcijańskiej i jego interdyscyplinarna metoda $w$ świetle nieznanych materiałów źródłowych z lat 1885-1900, Lwów-Kraków 2015. 
petycję x. Żyły o subw[encję] na podróż nauk[ową]”’. Dlatego po zakończeniu nauki w Paryżu ks. Żyła na semestr letni roku 1912/1913 mógł przenieść się do Monachium ${ }^{8}$. Uczęszczał tam na zajęcia z historii sztuki chrześcijańskiej i estetyki ${ }^{9}$. Następnie powrócił do Lwowa, gdzie kontynuował pracę katechety, jednocześnie został zatrudniony na Wydziale Teologicznym Uniwersytetu Lwowskiego, na którym w latach 1913-1917 pełnił funkcję adiunkta. W roku 1916 uzyskał tytuł doktora filozofii w zakresie historii sztuki i archeologii klasycznej na Wydziale Filozoficznym uL. Dnia 30 lipca 1917 roku ks. Władysław Żyła habilitował się na Wydziale Teologicznym Uniwersytetu Lwowskiego rozprawą Kościót oo. Dominikanów w Tarnopolu $(1749-1779)^{10}$.

W roku 1919 Rada Wydziału Teologicznego Uniwersytetu Jana Kazimierza we Lwowie rozpoczęła starania o utworzenie Katedry Historii Sztuki Kościelnej z Uwzględnieniem Archeologii Chrześcijańskiej. Jej kierownikiem miał zostać ks. doc. dr hab. Władysław Żyła. W piśmie wysłanym do Ministerstwa Wyznań Religijnych i Oświecenia Publicznego 26 kwietnia tego roku ówczesny dziekan Wydziału Teologicznego ks. prof. Franciszek Lisowski „przedstawia Ministerstwu kandydata na tę katedrę, który posiada według ogólnego przekonania wszelkie kwalifikacje naukowe i osobiste w wybitnym stopniu" ${ }^{11}$. Za kandydatem przemawiać miało jego świetne przygotowanie naukowe, znajomość kilku języków obcych oraz pokaźny dorobek naukowy ${ }^{12}$. Proszono o szybką nominację na profesora nadzwyczajnego, aby nowa katedra mogła rozpocząć funkcjonowanie od początku roku akademickiego 1919/1920 ${ }^{13}$.

Sprawa jednak przeciągała się, prawdopodobnie ze względu na trudną sytuację finansową młodego państwa. Kolejny dziekan ks. Szczepan

7 ABK, b. sygn., Dzienniczek Arcybiskupa Józefa Bilczewskiego, s. 261.

${ }^{8} \mathrm{~W}$ teczce personalnej ks. Władysława Żyły znajduje się pokaźna kolekcja listów, które kierował on do swego biskupa z podróżny naukowych i studiów prowadzonych w zakresie historii sztuki kościelnej w: Austrii (1911), Włoszech (1912), Francji (1912), Niemczech (1913), Portugalii (1913) i znów we Francji (1913). Patrz: ABK, b. sygn., teczka personalna ks. Władysława Żyły: Listy ks. Władysława Żyły do abp. Józefa Bilczewskiego z lat 1911-1913.

${ }_{9}$ AB K, b. sygn., teczka personalna ks. Władysława Żyły: List ks. Władysława Żyły do abp. Józefa Bilczewskiego, Monachium 12.05.1913.

${ }^{10} \mathrm{~J}$. Wołczański, Wydział Teologiczny Uniwersytetu..., dz. cyt., s. 378.

${ }^{11}$ DALO, Pismo dziekana WT UJK ks. Franciszka Lisowskiego do ministra wriop, Lwów 26.04.1919, f. 26, op. 5 , nr 669 .

${ }^{12} \mathrm{~J}$. Wołczański, Wydział Teologiczny Uniwersytetu..., dz. cyt., s. 379.

${ }_{13}$ Tamże, s. 378-38o. 
Szydelski ponowił prośbę we wrześniu 1919 roku, argumentując, że: „ogranicza swe żądanie [...] do minimum i do zaspokojenia potrzeb naprawdę nagłych i niezbędnych"14. Wkrótce też ks. Żyła zaczął otrzymywać propozycje z innych ośrodków naukowych. Rada Wydziału Teologii Uniwersytetu Warszawskiego upatrywała w nim doskonałego kandydata na kierownika Katedry Archeologii i Historii Sztuki Kościelnej. W liście dziekana tego wydziału ks. prof. Antoniego Szlagowskiego z 12 czerwca 1919 roku czytamy:

Szanowny Księże Profesorze!

Wydział nasz na sesji odbytej d. 23. maja r.b. uchwalił jednomyślnie powołać szanownego Księdza Profesora na Katedrę Archeologii i Sztuki Kościelnej jako profesora nadzwyczajnego od semestru zimowego 1919/20.

Mając Jego przyzwolenie, curriculum vitae oraz spis prac drukowanych przedstawiłem Jego kandydaturę J. Eks. Księdzu Arcypasterzowi, który postanowił się zwrócić do J. Eks. Arcyb. Bilczewskiego z prośbą o pozwolenie dla Szanownego Księdza Profesora do objęcia rzeczonej profesury. Nadto wniosłem na sesji senatu, który kandydaturę Jego odesłał do Ministerstwa z wnioskiem o utworzenie nowej Katedry i mianowanie na nią Szanownego Księdza.

O czym Go zawiadamiając, jednocześnie w imieniu całego Wydziału pozdrawiam naszego nowego kolegę i łączę wyrazy szacunku i poważania.

Ks. Antoni Szlagowski ${ }^{15}$

Podobna propozycja, choć może nie tak zaawansowana w staraniach, nadeszła z Wszechnicy Krakowskiej. O ile oferta Uniwersytetu Jagiellońskiego nie wzbudziła entuzjazmu ks. Żyły, o tyle propozycja warszawska wydała mu się interesująca. Dlatego w liście kierowanym do abp. Józefa Bilczewskiego ks. Żyła pisał:

choć byłoby mi bardzo przykro rozstawać się ze Lwowem, archidiecezją i [...] gronem profesorskim, zwłaszcza że Uniwersytet Lwowski czyni też usilne i szczere starania o kreowanie Katedry Historii Sztuki, jednak rozważywszy rzecz dokładniej, sądzę, że nie oglądając się na żadne przywiązania

\footnotetext{
${ }^{14}$ DALO, Pismo dziekana wT U K ks. Sz. Szydelskiego do ministra wriop, Lwów 25.09.1919, f. 26 , op. 5 , nr 669 .

${ }^{15}$ ABK, b. sygn., teczka personalna ks. W. Żyły: List ks. Antoniego Szlagowskiego do ks. Władysława Żyły, Warszawa 19.06.1919.
} 
i kierując się jedynie rozumem, oświeconym wiarą, należałoby tę propozycję warszawską przyjąć, naturalnie jeśli Ekscelancya na to pozwoli ${ }^{16}$.

Ksiądz Żyła uważał Uniwersytet Warszawski za miejsce, gdzie kształcą się przyszli naukowcy. To właśnie oni, jako późniejsi profesorowie, mieli rozpowszechniać wiedzę na uczelniach całego kraju, dlatego inne uniwersytety powinny „oddać Warszawie swoje najlepsze siły”. Prosił o zwolnienie $\mathrm{z}$ archidiecezji i pozwolenie na przejście do archidiecezji warszawskiej ${ }^{17}$. W kwestii tej u abp. Bilczewskiego interweniowali także ks. Antoni Szlagowski, dziekan Wydziału Teologicznego $\mathrm{UW}^{18}$, oraz arcybiskup warszawski Aleksander Kakowski ${ }^{19}$. Jednak ze względu na starania UృK o powołanie Katedry Historii Sztuki Kościelnej oraz fakt, że jedynym kandydatem na jej kierownika był ks. Żyła, metropolita lwowski odmówił zgody na zupełne przejście do Warszawy, dał jedynie przyzwolenie na prowadzenie przez kapłana wykładów naprzemiennie (w cyklu zmian semestralnych) na obu uniwersytetach ${ }^{20}$.

Prorektor Uniwersytetu Jana Kazimierza ks. Kazimierz Wais w czasie wizyty w ministerstwie wriop jesienią 1919 roku interweniował w sprawie powołania Katedry Historii Sztuki Kościelnej. Mimo to kwestia ta wydawała się wciąż bardzo niepewna. Dlatego też niezależnie od kwestii powołania katedry Rada Wydziału Teologicznego postanowiła zlecić ks. Żyle prowadzenie wykładów $\mathrm{z}$ historii sztuki w pełnym wymiarze siedmiu godzin tygodniowo $^{21}$. Po zmianie dziekana we wrześniu niemal natychmiast wysłano kolejne pismo do ministra wriop, z prośbą o przychylenie się do wcześniejszego wniosku Wydziału ${ }^{22}$. Sprawę tę ostatecznie zakończono dopiero 30 października 1919 roku. Ministerstwo wRiop pismem z tego dnia zawiadamiało, że na podstawie rozporządzenia wydanego 18 października 1919 roku Naczelnik Państwa mianował ks. Władysława Żyłę,

\footnotetext{
${ }^{16}$ ABK, b. sygn., korespondencja abpa Józefa Bilczewskiego 1919: List ks. Władysława Żyły do abp. Józefa Bilczewskiego, Kraków 24.06.1919.

${ }^{17}$ ABK, b. sygn., korespondencja abpa Józefa Bilczewskiego 1919: List ks. W. Żyły do abp. J. Bilczewskiego, Kraków 24.06.1919.

${ }^{18}$ ABK, b. sygn., korespondencja abpa Józefa Bilczewskiego 1919: List dziekana WT UW A. Szlagowskiego do abp. Józefa Bilczewskiego, Warszawa 15.06.1919.

${ }_{19}$ J. Wołczański, Wydział Teologiczny Uniwersytetu..., dz. cyt., s. 379n.

${ }^{20}$ Tamże, s. 380 .

${ }^{21}$ Tamże, s. 379.

${ }^{22}$ DALO, Pismo dziekana wT Ujk ks. Szczepana Szydelskiego do ministra wriop, Lwów 25.09.1919, f. 26, op. 5, nr 669 .
} 
docenta prywatnego, profesorem nadzwyczajnym historii sztuki kościelnej z uwzględnieniem archeologii chrześcijańskiej na Uniwersytecie Lwowskim Z ważnością od dnia 1 października 1919 roku $^{23}$.

Uniwersytet Warszawski podjął u władz U JK starania o udzielenie nowo mianowanemu profesorowi urlopu na II i in trymestr roku akademickiego 1919/1920, aby mógł poprowadzić wykłady w stolicy; starania Uw poparł dziekan Wydziału ks. Szczepan Szydelski. Prośbę tę odrzucił jednak sam ks. Żyła, tłumacząc, że ogłosił już całoroczne wykłady, a ponadto powinien zająć się organizacją Katedry Sztuki Kościelnej z Uwzględnieniem Archeologii Chrześcijańskiej. Podobne pismo z UW wpłynęło do sekretariatu WT UJK pod koniec roku 1919/1920. I tym razem zapraszano ks. Żyłę do przeprowadzenia wykładów w Warszawie. Ten zgodził się na wykłady, jednak tylko w III trymestrze roku akademickiego. Naukowiec uzyskał akceptację Rady Wydziału 2 czerwca 1920 roku. Prowadzone przez niego zajęcia zaplanowano na III trymestr roku 1920/1921 $1^{24}$. Na tym samym posiedzeniu Rady Wydziału uchwalono wniosek o rozpoczęcie starań dotyczących mianowania ks. Władysława Żyły profesorem zwyczajnym ad personam. W piśmie do Ministerstwa dziekan Wydziału Teologicznego ujk ks. Szydelski prosi o mianowanie ks. Żyły profesorem zwyczajnym z początkiem roku akademickiego 1920/1921 $1^{25}$.

I tym razem na ogłoszenie nominacji przyszło trochę poczekać. Dnia 3 lutego 1921 roku wysłano do ministra wriop kolejne pismo w tej sprawie, prosząc o jak najszybsze zamianowanie Żyły profesorem zwyczajnym ${ }^{26}$. Odpowiedź w tej kwestii została przesłana na Lwowski Uniwersytet dopiero 4 lipca 1921 roku. Informowano, że:

Naczelnik Państwa zamianował Przewielebnego Księdza postanowieniem z dnia 23 czerwca 1921 r. zwyczajnym profesorem Historii Sztuki Kościelnej w Uniwersytecie Jana Kazimierza we Lwowie z ważnością nominacji od dnia 1 lipca 1921 r. $^{27}$

\footnotetext{
${ }^{23}$ DALO, Pismo z mWriop. Pismo nominacyjne na profesora nadzwyczajnego dla ks. W. Żyły, Warszawa 30.10.1919, f. 26, op. 5, nr 669.

${ }^{24}$ J. Wołczański, Wydział Teologiczny Uniwersytetu..., dz. cyt., s. 381.

${ }^{25}$ DALO, Pismo dziekana wT UJK ks. Sz. Szydelskiego do ministra wriop, Lwów 3.06.1920, f. 26, op. 5, nr 669 .

${ }^{26}$ DALO, Pismo dziekana wT Ujk ks. Sz. Szydelskiego do ministra wriop, Lwów 3.02.1921, f. 26 , op. 5 , nr 669 .

${ }^{27}$ DALO, Pismo ministra wriop Tadeusza Łopuszańskiego do dziekana wT Ujk ks. Żyły, Warszawa, 4.07.1921, f. 26, op. 5, $\mathrm{nr} 669$.
} 
Na posiedzeniu Rady Wydziału 26 czerwca 1920 roku Żyła wystąpił z prośbą o mianowanie ks. Leon Issakowicza asystentem w Katedrze Historii Sztuki Kościelnej. Był on świetnie zapowiadającym się studentem ks. Żyły, niezmiernie zainteresowanym zagadnieniami związanymi z historią sztuki. Rada Wydziału poparła prośbę kierownika katedry. Dnia 20 lipca 1920 roku wysłano w tej sprawie pismo do ministra wRiop. Ministerstwo prośbę rozpatrzyło pozytywnie, co potwierdza pismo z 4 października $1920 \mathrm{roku}^{28}$.

$\mathrm{W}$ roku następnym, także na wniosek ks. Żyły, Rada Wydziału Teologicznego powierzyła ks. Issakowiczowi funkcję starszego asystenta w Instytucie Historii Sztuki Kościelnej na lata akademickie 1921/1922 i 1922/1923. Jednak po upływie roku ks. Issakowicz zrezygnował $\mathrm{z}$ asystentury, tłumacząc się nadmiarem obowiązków. Na jego miejsce nominowano ks. Adama Gyurkovicha, wikariusza parafii św. Marii Magdaleny. Stanowisko to zajmował od 6 października 1922 do 15 lutego 1926 roku, kiedy to złożył rezygnację ze względu na obowiązki parafialne ${ }^{29}$.

Wśród licznych obowiązków uczelnianych ks. prof. Żyły można wymienić zasiadanie w kilku komisjach zajmujących się m.in. pomocą materialną dla uczonych w Związku Radzieckim, tworzeniem programów na uroczystości nadawania tytułów doctora honoris causa czy też organizacją akademii ku czci znanych artystów i uczonych. Uczestniczył również w posiedzeniach komisji do spraw lokali ${ }^{30}$. Jednak najważniejszymi funkcjami, jakie pełnił we lwowskiej wszechnicy, były stanowiska dziekana i prodziekana Wydziału Teologicznego ${ }^{31}$.

Do działalności pozauniwersyteckiej należy zaliczyć członkostwo w Komisjach Konserwatorów dla Małopolski Wschodniej i Historii Sztuki Polskiej Akademii Umiejętności. Należał do Lwowskiego Towarzystwa Naukowego i Polskiego Towarzystwa Teologicznego. W latach 1923-1924 był kustoszem Muzeum Lubomirskich we Lwowie ${ }^{32}$. Natomiast w roku 1925 rozpoczął prace nad organizacją Muzeum Archidiecezjalnego.

Wykłady ks. Żyły początkowo adresowane były do studentów teologii. W latach 1921-1925 rozwinięte zostały o tematy dla studentów pozostałych

\footnotetext{
${ }^{28}$ J. Wołczański, Wydział Teologiczny Uniwersytetu..., dz. cyt., s. 382.

${ }^{29}$ Tamże, s. 383.

30 Tamże, s. 162, 167n.

${ }^{31}$ Dziekanem był w roku akademickim 1921/1922, a funkcję prodziekana sprawował w roku 1922/1923. Zob. J. Wołczański, Wydział Teologiczny Uniwersytetu..., dz. cyt., s. 378; K. Gabryel, Żyła Władysław, [w:] Słownik polskich teologów katolickich, dz. cyt., s. 560.

${ }^{32} \mathrm{~J}$. Wołczański, Wydział Teologiczny Uniwersytetu..., dz. cyt., s. 378.
} 
fakultetów. Właśnie dlatego wśród tematów zajęć prowadzonych przez tego wybitnego naukowca znaleźć można zarówno te związane z historią sztuki, jak i te związane bezpośrednio ze Lwowem i jego sztuką sakralną. Obok wykładów ks. Żyła prowadził od 1920 roku także seminarium naukowe. Nie zachowały się żadne informacje dotyczące liczby uczestników tych zajęćs ${ }^{33}$.

W ciągu kilkuletniej działalności ks. Władysław Żyła nie zdołał wykształcić swojego następcy. Przygotowywał on co prawda recenzję pracy doktorskiej ks. Leona Issakowicza noszącej tytuł Płyty grobowe katedry ormiańskiej, jednak nie udało się doprowadzić do obrony rozprawy ${ }^{34}$.

Ksiądz Żyła pozostawił po sobie niezbyt obfity dorobek pisarski, który liczy 36 pozycji, a wśród nich monografie książkowe, sprawozdania i relacje z podróży, własne artykuły, a także recenzje prac i publicystyka. Całość podzielić można na trzy grupy. Pierwsza, najważniejsza, dotyczyła ochrony i konserwacji zabytków, druga grupa to artykuły omawiające zabytki z terenów Polski, szczególnie zaś Małopolski Wschodniej, ostatnią grupę stanowią artykuły poświęcone sztuce europejskiej35.

Tę obiecującą karierę naukową przerwała nagła śmierć ks. Żyły. Zmarł 18 maja 1925 roku we Lwowie w wieku 49 lat. O tym, jak niezastąpioną okazał się osobą, świadczy najlepiej fakt, że już w 1926 roku zlikwidowano Katedrę Sztuki Kościelnej na Uniwersytecie Lwowskim. Nie udało się bowiem znaleźć kandydata dostatecznie przygotowanego do jej prowadzenia ${ }^{36}$. Ksiądz Żyła został pochowany 20 maja 1925 roku na cmentarzu Janowskim we Lwowie, zaś nabożeństwo żałobne prowadził ks. Kazimierz Wais ${ }^{37}$.

Tak zmarłego wspominał prof. Edmund Buldanda:

wielką stratę poniosła nauka polska, stratę na razie niezastąpioną poniósł Wydział Teologiczny Uniwersytetu Jan Kazimierza, stratę poniosła diecezja lwowska, przyjaciele stracili w nim oddanego, wiernego a serdecznego i głębokiej dobroci towarzysza i lojalnego kolegę ${ }^{38}$.

${ }^{33}$ Lista wykładów ks. prof. dra hab. W. Żyły - patrz aneks.

${ }^{34} \mathrm{~J}$. Wołczański, Wydział Teologiczny Uniwersytetu..., dz. cyt., s. 388.

${ }^{35}$ Spis publikacji ks. prof. dra hab. W. Żyły - patrz aneks.

${ }^{36}$ J. Draus, Uniwersytet Jana Kazimierza we Lwowie 1918-1946. Portret kresowej uczelni, Kraków 2007, s. 40.

${ }^{37}$ Kronika Katedry Lwowskiej cz. 1 (1923-1927), http://www.lwow.com.pl/rocznik/katedra/kronika-katedry1923-27.html (7.04.2014).

${ }^{38}$ E. Bulanda, Sp. Ks. Władysław Żyła, dz. cyt., s. 419. 


\section{Aneks 1}

\section{Zestawienie wykładów prowadzonych przez ks. prof. Władysława Żyłę na Uniwersytecie Jana Kazimierza we Lwowie w latach 1918-1925}

Tabela 1. Tematy wykładów z historii sztuki ogólnej

\begin{tabular}{|l|l|}
\hline $\begin{array}{l}\text { Lata wykładania } \\
\text { (trymestr w nawiasie) }\end{array}$ & Temat wykładów \\
\hline $\begin{array}{l}\text { 1918/1919 (I), } \\
1923 / 1924 \text { (I-II) }\end{array}$ & Sztuka kościelna w epoce romańskiej i gotyckiej \\
\hline $1919 / 1920$ (I) & $\begin{array}{l}\text { Historia sztuki kościelnej do epoki renesansu } \\
\text { włącznie }\end{array}$ \\
\hline $1919 / 1920$ (II) & Dzieje sztuki religijnej w epoce średniowiecznej \\
\hline $1920 / 1921$ (I-II) & Renesans w Kościele \\
\hline $1920 / 1921$ (III) & Sztuka Kościelna w XVIII wieku \\
\hline $1921 / 1922$ (I-III) & Historia sztuki kościelnej do epoki romańskiej \\
\hline $1922 / 1923$ (I-II) & Epoka renesansu \\
\hline $1922 / 1923$ (III) & Barok, rokoko, klasycyzm \\
\hline $1923 / 1924$ (I-II) & Sztuka starochrześcijańska i bizantyjska \\
\hline $1924 / 1925$ (I-II) & Historia sztuki kościelnej w zarysie \\
\hline
\end{tabular}

Tabela 2. Tematy wykładów z muzealnictwa i sztuki lwowskiej

\begin{tabular}{|l|l|}
\hline $\begin{array}{l}\text { Lata wykładania } \\
\text { (trymestr w nawiasie) }\end{array}$ & Temat wykładów \\
\hline $1918 / 1919$ (I) & Sztuka kościelna we Lwowie w XVII i XVIII wieku \\
\hline $1919 / 1920$ (I-II) & Lwowska sztuka kościelna w XIX wieku \\
\hline $1920 / 1921$ (I-II) & Lwowska sztuka gotycka i renesansowa \\
\hline $1920 / 1921$ (III) & $\begin{array}{l}\text { Lwowska architektura i rzeźba w epoce renesansu } \\
\text { i baroku XVII wieku }\end{array}$ \\
\hline $1922 / 1923$ (III) & Lwowskie kościoły XVIII wieku \\
\hline $1923 / 1924$ (I-II) & Lwowskie kościoły i cerkwie XVIII wieku \\
\hline $1923 / 1924$ (III) & Lwowskie kościoły drugiej połowy XVIII wieku \\
\hline
\end{tabular}


Tabela 3. Tematy wykładów monograficznych

\begin{tabular}{|l|l|}
\hline $\begin{array}{l}\text { Lata wykładania } \\
\text { (trymestr } \\
\text { w nawiasie) }\end{array}$ & Temat wykładów \\
\hline $1918 / 1919(\mathrm{I})$ & $\begin{array}{l}\text { Wieczerza Pańska w sztuce pod względem ikonograficznym } \\
\text { i stylistycznym }\end{array}$ \\
\hline $1919 / 1920(\mathrm{I})$ & Katedra na Wawelu $^{1}$ \\
\hline 3 III 1924 & Bazylika starochrześcijańska $^{2}$ \\
\hline
\end{tabular}

1 J. Wołczański, Wydział Teologiczny Uniwersytetu..., dz. cyt., s. 387.

2 Wykład otwarty dla słuchaczy.

\section{Aneks 2}

\section{Spis publikacji ks. Władysława Żyły}

Kościół oo. Dominikanów w Tarnopolu (1749-1799), Lwów 1917.

Zadania duchowieństwa wobec sztuki kościelnej w czasie wojennym, „Gazeta Kościelna” 25 (1918) nr 2, s. 14-15.

Zabytki kościelne w Wilnie, „Gazeta Kościelna” 25 (1918) nr 3, s. 23-24.

Dworek Sióstr Opatrzności w Lackie, „Gazeta Kościelna” 25 (1918) nr 4, s. 36-37.

Portret J.E. ks. Arcybiskupa Bilczewskiego w auli uniwersyteckiej, „Gazeta Kościelna” 25 (1918) nr 5, s. 41.

Nieco o kościele anglikańskim, „Gazeta Kościelna” 25 (1918) nr 5, s. 41.

Ważniejsze rady i wskazówki, dotyczące ochrony zabytków kościelnych, „Gazeta Kościelna" 25 (1918) nr 5, s. 44; 26 (1919), nr 1, s. 6.

Katedra ormiańska we Lwowie, Kraków 1919.

Kościoły gotyckie w Małopolsce i na Mazowszu, „Gazeta Kościelna” 27 (1920) nr 1, s. 3-4.

O metodzie w historii sztuki starochrześcijańskiej, „Przegląd Powszechny” 38 (1920)

t. 145/146, s. 106-119.

El Greco jako impresjonista $i$ wizjoner. Charakter i geneza jego twórczości artystycznej, „Gazeta Kościelna” 27 (1920), s. 119-123.

Rozwój w stylu twórczości Rafaela, „Gazeta Lwowska” (1920), s. 146-147.

Pietro Perugio, „Gazeta Lwowska” (1920), s. 23.

Najstarszy zabytek z epoki romańskiej we wschodniej Małopolsce, „Słowo Polskie” 25 (1920) nr 226-230.

Marmury Wita Stwosza, „Słowo Polskie” 25 (1920) nr 277-278. 
Projekt nowego Kościoła we Lwowie, „Słowo Polskie” 25 (1920) nr 507, 514, 516, $518,520$.

Dante a sztuka, „Gazeta Kościelna” 29 (1922) nr 37, s. 442; nr 40, s. 464; 30 (1923) nr 1, s. 2.

Kościół i klasztor Dominikanów we Lwowie, Lwów 1923.

Wiec salzburski w sprawie ochrony zabytków, „Gazeta Kościelna” 19 (1911) nr 2, s. 14. Podróży na wschód, „Gazeta Kościelna” 20 (1912) nr 3, s. 24-25; nr 4, s. 39; nr 5, s. 41-43.

Korespondencja z Bergamo, „Gazeta Kościelna” 21 (1913) nr 1, s. 4.

Ukraińskie Muzeum Nacjonalne we Lwowie, „Gazeta Kościelna” 25 (1918) nr 4, s. 38-39.

Rec.: T. Szydłowski: Ruiny Polski, Kraków 1919, „Gazeta Kościelna” 27 (1920) nr 1, s. 6 .

Jak należy patrzeć na dzieła sztuki, „Gazeta Kościelna” 27 (1920) nr 2, s. 17.

Rec.: T. Szydłowski: Ruiny Polski, Kraków 1919, „Przegląd Powszechny” 38 (1920)

t. $145 / 146$, s. 217-219.

Zniszczone przez wojnę pomniki kultury polskiej, „Słowo Polskie” 25 (1920) nr 176177.

W sprawie zabudowania placu obok kościoła Dominikanów, „Słowo Polskie” 25 (1920) nr 197.

Jubileusz prof. Antoniewicza, „Słowo Polskie” 25 (1920) nr 215.

Zabytki Dobromila i okolicy, „Słowo Polskie” 25 (1920) nr 244-245.

Z badań nad plastyka Średniowiecza, „Słowo Polskie” 25 (1920) nr 300, 302, 304. Wystawa zdobnictwa ludwisarskiego, „Słowo Polskie” 25 (1920) nr 484, 487, 489, 518.

Rec.: T. Szydłowski: Ruiny Polski, Kraków 1919, „Kwartalnik Historyczny” 33 (1919), s. 86 .

Problem nowego stylu w architekturze polskiej, „Gazeta Kościelna” 29 (1922) nr 37, s. 438 .

Muszyna i jej zabytki, „Gazeta Kościelna” 31 (1924) nr 8, s. 96.

Z podróży po Włoszech, „Przegląd Współczesny” 4 (1925) nr 33, s. 112-116.

Rec.: F Dettloff: Stosunki artystyczne biskupa poznańskiego Uriela z Górki z Norymberga, Poznań 1919, „Przegląd Powszechny” 38 (1920) t. 145/146, s. 397-399. 